Journal of Biotechnology and Strategic Health Research

\author{
Araştırma Makalesi / Research Article
}

http://dergipark.org.tr/tr/pub/bshr

\title{
COVID-19 Hikayesine Göre Oral Hijyen Alışkanlığının ve Periodontal Hastalık Hikayesinin Teledişhekimliği Aracılığıyla Değerlendirilmesi: Kesitsel Araştırma
}

\author{
Evaluation Of Oral Hygiene Habits And Periodontal Disease According \\ To The COVID-19 History By Teledentistry: A Cross-Sectional Study
}

(D) Ezgi Gürbüz, (D) Ezgi Ceylan

Kütahya Sağlık Bilimleri Üniv. Diş Hekimliği Fakültesi Periodontoloji A.D Dalı, Evliya Çelebi Yerleşkesi Tavşanlı Yolu 10. km KÜTAHYA ORCID ID: Ezgi Gürbüz https://orcid.org/0000-0001-8774-8537, Ezgi Ceylan https://orcid.org/0000-0003-1835-0474

^Sorumlu Yazar / Corresponding Author: Ezgi GÜRBÜZ, e-posta / e-mail: ezgi.dogan@ksbu.edu.tr

Geliş Tarihi / Received : 21-09-2021 Kabul Tarihi / Accepted: 03-11-2021 Yayın Tarihi / Online Published: 30-12-2021

Gürbüz E., Ceylan E. COVID-19 Hikayesine Göre Oral Hijyen Alışkanlığının ve Periodontal Hastalık Hikayesinin Teledişhekimliği Aracılığıyla Değerlendirilmesi: Kesitsel Araştırma, J Biotechnol and Strategic Health Res. 2021; 5(3):200-206

\footnotetext{
$\ddot{O} z$

Amaç Bu anket çalışmasında teledişhekimliği ile bireylerin oral hijyen alışkanlıklarının, periodontal hastalık hikayelerinin değerlendirilmesi ve COVID-19 hikayelerine göre oral hijyen, periodontal hastalık durumlarının karşılaştırılması amaçlandı.

Materyal ve Bu kesitsel çalışmaya pandemi öncesinde fakültemize başvurmuş hastalardan teledişhekimliği yolu ile ulaşılan hastalar dahil edildi. Onamı alınan hastalara 4 bölüm ve

Metod 25 sorudan oluşan bir anket telefon konuşması aracılığıyla uygulandı. Anketin ilk bölümünde demografik bilgiler, medikal hikaye, sigara içme alıșkanlığı ve COVID-19 hikayesi (COVID-19 geçiren [COVID(+)] veya geçirmeyen [COVID(-)]) sorgulanırken sonraki üç bölümde dental hijyen (DH), cevresel dental hijyen (CH), periodontal hastalık hikayesi $(\mathrm{PH})$ değerlendirildi. Bu üç bölümdeki sorulara verilen yanıtlar, artan değerler olumsuz tutumu sembolize edecek şekilde puanlandırıldı. Puanların toplamından elde edilebilecek minimum ve maksimum değerler dikkate alınarak düşük, orta ve yüksek değer aralıklarının yer aldığı DH, ÇH ve PH ölçekleri olușturuldu. Gruplar ölçeklerden alınan ortalama değer ve ölçek aralıklarında dağılım açısından kıyaslandı.

Bulgular Anketi tamamlayan 154 kișinin 84’ü (\%54.5) COVID(+) grubunda yer alırken 70’i (\%45.5) COVID(-) grubunda yer aldı. İki grup arasında yas, cinsiyet, sistemik hastalık varlığı ve ilaç kullanımı açısından istatistiksel olarak anlamlı farklılık bulunmazken sigara alıșkanlığı açısından farklılık tespit edildi. Sigara içen kişi sayısı COVID(-) grubunda daha fazla bulundu $(\mathrm{p}=0.034)$. Mann Whitney $\mathrm{U}$ ve Chi-square testlerinin sonuçlarına göre iki grup arasında ölçek değerleri ve hastaların ölçek aralıklarına dağılımları açısından istatistiksel farklılık görülmedi.

Sonuç Bu çalışmada periodontal durum ile COVID-19 ilişkisini destekleyecek kanıt elde edilememiştir ve teledişhekimliğiyle belirlenen periodontal açıdan riskli bireylerin yer aldığı, COVID-19 komplikasyon verilerine yer verilen, katılımcı sayısının fazla olduğu ileri klinik çalışmalara ihtiyaç vardır.

Anahtar COVID-19; ağız hijyeni; periodontal hastalıklar

Kelimeler

Abstract

Objective To evaluate oral hygiene habits and periodontal disease status with teledentistry and to compare oral hygiene and periodontal disease status according to the COVID-19 history.

Materials and Patients who had applied to our faculty before the pandemic and were reached via teledentistry were included. A questionnaire consisting of 4 sections and 25 questions was administered Methods through telephone conversation. Demographic information, medical history, smoking habits, and COVID-19 history (with [COVID(+)] or without COVID-19 [COVID(-)]) were questioned in the first section, while dental hygiene (DH), environmental dental hygiene (EH), history of periodontal disease (PH) were evaluated in the next three sections. The answers were scored in a way that increased values symbolize negative attitude. Taking into account the minimum and maximum values that can be obtained from the sum of the scores; DH, EH and PH scales with low, medium and high value ranges were created. The groups were compared in terms of the mean value from the scales and the distribution in the scale ranges.

Results Of the 154 people who completed the survey, 84 (54.5\%) were in the COVID(+), while $70(45.5 \%)$ were in the COVID(-). While there was no statistically significant difference between the two groups in terms of age, gender, presence of systemic disease and medication use; there was a difference in smoking habit. The number of smokers was higher in the COVID(-) ( $p=0.034)$. According to the results of Mann Whitney $U$ and Chi-square tests, there was no statistical difference between the two groups in terms of scale values and distribution of patients to scale ranges.

Conclusion There was no evidence to support the relationship between periodontal status and COVID-19, and further clinical studies with a higher number of participants, including individuals with periodontal risk determined by teledentistry, and COVID-19 complication data are needed.

Keywords COVID-19; oral hygiene; periodontal diseases
} 


\section{GIIRIŞ}

Küresel olarak yayılmakta olan yeni koronavirüs (SARSCoV-2), tıp ve diş hekimliği camiasında endişeye sebep olmaktadır. SARS-CoV-2; göz, burun veya ağız mukozası ile doğrudan veya dolaylı temas yoluyla bulaşmaktadır., ${ }^{1,2}$ $\mathrm{Bu}$ virüs, insan hücrelerini anjiyotensin dönüştürücü enzim-2 (ACE-2) reseptörleri aracılığıla etkiler. ACE-2 reseptörleri üst solunum yolları ve salgı bezi kanallarının epitel hücrelerinde yaygın olarak dağıldığından, bu bölgeler enfeksiyonun ilk hedefleridir. ${ }^{3-5}$ Özellikle viral germler için rezervuar oluşturabilen dil başta olmak üzere ağız kavitesinde de bu reseptörler mevcuttur. Bu nedenle, ağız bölgesindeki viral yükü azaltmak için diş fırçalama ve dil temizliği önemlidir. ${ }^{2,6}$

SARS-CoV-2'nin yol açtığı Koronavirüs hastalığı 2019 (COVID-19); ateş, öksürük, halsizlik gibi semptomların yanı sıra pnömoni, akut solunum sıkıntısı sendromu, çoklu organ disfonksiyonu gibi şiddetli rahatsılılklara da neden olur. ${ }^{7}$ COVID-19'un ciddi komplikasyonları; yaş, cinsiyet, hipertansiyon, kardiyovasküler hastalık, diyabet ve obezite gibi risk faktörleriyle ilişkilendirilmektedir. ${ }^{8}$ COVID-19 mortalitesi açısından risk yaratan bu faktörler aynı zamanda periodontal hastalık açısından da risk oluşturmaktadır ve ortak risk faktörleri iki hastalık arasında ilişki olabileceğini düşündürmektedir. ${ }^{9}$ Ayrıca şiddetli seyreden COVID-19'da görülen sitokin fırtınası, patofizyolojisinde sitokinlerin önemli rol oynadığı periodontitisin COVID-19 ile ilişkilendirilebileceği hipotezini desteklemektedir. ${ }^{10}$

Yaygın risk faktörlerinin yanı sıra ağız boşluğu ile alt solunum yolu birbiriyle yakın ilişki içerisindedir. Bu iki anatomik yapının ilişkisi sonucunda ağızdaki patojenlerin akciğere aspirasyonu söz konusu olabilir. ${ }^{11}$ Aynı zamanda periodontal patojenlerin neden olduğu konak cevabının neticesinde üretilen sitokinler ve enzimler de alt solunum yolu epitelinde değişikliğe sebep olarak viral enfeksiyonu kolaylaştırabilirler. Takahashi ve ark. ${ }^{12}$ periodontal patojenlerin çeşitli mekanizmalarla COVID-19 seyrini etkile- yebileceğini belirtmişler ve bu mekanizmaların patojenlerin aspire edilmesinin yanı sira patojenler tarafindan ACE-2 ekspresyonunun teşvik edilmesi ve SARS-CoV2'nin başak (S) proteininin yıkıma uğratılarak viral enfeksiyonun kolaylaştırılması şeklinde olabileceği speküle edilmiştir.

COVID-19 pandemisi, dünya çapında mevcut sağlık sistemlerinin zorluklarla karşılaşmasına sebep olmuştur. Damlacık ve temas yoluyla yayılan virüs, sağlık çalışanlarının hasta ile yüz yüze etkileşiminde bulaş riskine sebep olabilmektedir. Dental tedaviler; nazo-orofaringeal bölgenin yakından incelenmesi, muayenesi ve terapötik müdahalelerini içerdiğinden diş hekimleri koronavirüs enfeksiyonundan etkilenebilir. ${ }^{5}$ COVID-19 etkisiyle dijital yaşam tarzının benimsenmeye başladığı dünyamızda tıp ve diş hekimliği alanında da bulaş riskini azaltacak uygulamalara gidilmeye başlanmıştır. ${ }^{13}$ Bu uygulamaların başında gelen teledişhekimliği, hasta ile doğrudan temas kurulmadan bilgi teknolojisi kullanımı yoluyla diş bakımı ve tedavileri konusunda rehberlik veya eğitim verilmesi şeklinde uygulanmaktadır. ${ }^{14}$ Yeni bir kavram olmayan teledişhekimliği Amerika Birleşik Devletleri (ABD) ordusu tarafından dünyanın her yerindeki ABD birliklerine hizmet etmek için 1994 yılında başlatılmıştır ve bu ilk uygulama yaşadıkları yerin 120 mil uzağındaki bir kliniğe periodontal cerrahi için sevk edilen 15 hasta üzerinde yapılmıştır. ${ }^{15}$ Cerrahi sonrası kontrollerin, sütur alma işleminin lokal klinikte yapıldığı ve cerrahinin yapıldığı uzman hekim kliniğiyle ağız içi fotoğraflarla iletişimin kurulduğu çalışmada hastaların büyük çoğunluğu bu uygulamayla iyi tedavi aldıklarını belirtmişlerdir.

Periodontal hastalıkta idamenin önemi ve periodontal hastalık ile COVID-19 arasındaki olası ilişki göz önünde bulundurulduğunda bu çalışmada; teledişhekimliği ile bireylerin oral hijyen alışkanlıklarının, periodontal hastalık hikayelerinin değerlendirilmesi ve COVID-19 hikayelerine göre oral hijyen, periodontal hastalık durumlarının karşılaştırılması amaçlandı. 


\section{YÖNTEM}

Bu kesitsel çalışmaya pandemi öncesinde Kütahya Sağllk Bilimleri Üniversitesi Diş Hekimliği Fakültesi Periodontoloji Ana Bilim Dalı̉na başvurmuş hastalardan teledişhekimliği yolu ile ulaşllan hastalar dahil edildi. Teledişhekimliği, hastaların hastane otomasyon sisteminde kayıtlı telefon numaraları yolu ile telefon konsültasyonu şeklinde uygulandı. Telefon ile ulaşılan bireylere çalışma hakkında bilgi verilerek gönüllü olmak isteyenlere kısa mesaj (SMS) yoluyla bilgilendirilmiş gönüllü onam formu linki (https:// forms.gle/k6bDws2gGBmGuErj9) aktarıldı.

Onamı alınan hastalara 4 bölüm ve 25 sorudan oluşan bir anket telefon konuşması aracilığıyla uygulandı (Şekil 1). Bu anket çalışmasına 18 yaş üzeri, Türkçe dilini bilen, okuyan ve yazan, telefon görüşmesi yapmaya engel olabilecek bir işitme, konuşma veya görme problemi olmayan, SMS iletişimini ve internet kullanımını mümkün kılan telefonu olan kişiler dahil edildi.

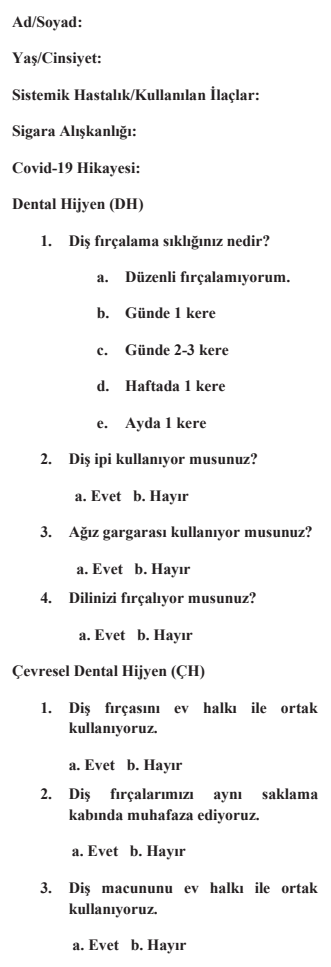

Anketin ilk bölümünde demografik bilgiler, medikal hikaye, sigara içme alıskanlığı ve COVID-19 hikayesi (COVID-19 geçiren [COVID(+)] veya geçirmeyen [COVID(-)]) sorgulanırken sonraki üç bölümde dental hijyen (DH), çevresel dental hijyen (ÇH), periodontal hastalık hikayesi $(\mathrm{PH})$ değerlendirildi. Bu üç bölümdeki sorulara verilen yanıtlar, artan değerler olumsuz tutumu sembolize edecek şekilde puanlandırıldı. Puanların toplamından elde edilebilecek minimum ve maksimum değerler dikkate alınarak düşük (0-2), orta (3-4) ve yüksek (5-7) değer aralıklarının yer aldığı DH, ÇH ve PH ölçekleri oluşturuldu.

Ankette yer alan DH ve ÇH sorularının oluşturulmasında González-Olmo ve ark.'nın ${ }^{16}$ çalışmalarında yer verdikleri anketten yardım alınırken PH sorularının hazırlı̆̆ında ise Gilbert ve Nuttall'ın ${ }^{17}$ yayınlarında değerlendirdikleri soruların bir kısmından faydalanıldı. Uygulanan anket sorularına verilen yanıtların puanlandırılmasında Ruíz-López Del Prado ve ark.'na ${ }^{18}$ ait puanlama örneği referans alındı. Puanların ölçeğe dönüştürülmesinde ise Kamel ve ark.nın ${ }^{19}$ yayınına benzer ölçeklendirme kullanıldı.

\section{İstatistiksel analizler}

İstatistiksel analizler Python 3 Jupyter Notebook ve Pandas, Scipy, Numpy, Seaborn kütüphaneleri aracılığ1 ile gerçekleştirildi. 2x2 kategorik değişken arasındaki oransal farklar Fischers' exact testi ile değerlendirilirken nxn boyutlu tablolarda kategorik değişkenlerin oransal farkları Chi-square testi ile değerlendirildi. Normal dağılım göstermeyen sürekli değişkenlerin iki grup arasındaki ortalama farklarının analizinde Mann Whitney U testi kullanıldı ve ikiden fazla grup arasındaki ortalama farklarının analizinde ise Kruskal-Wallis testinden faydalanıldı. Normal dağılmayan iki sürekli değişkenin birbirleri arasında olan ilişki Spearman korelasyon analizi ile test edildi. Sürekli değişkenlerin normallik testleri Kolmogorov-Smirnov testi ile gerçekleştirilirken istatistiksel anlamlılık alfa $=0,05$ seviyesinde kabul edildi.

Şekil 1. Çalısmada uygulanan anket 


\section{BULGULAR}

Ankete katılım sağlayan 154 kişinin \%33.8'i (n=52) erkek, \%66.2'si ( $n=102$ ) kadın katılımcıydı ve ortalama yaş değeri 40.86 olarak tespit edildi. Anketi tamamlayanların 84’ü (\%54.5) COVID(+) grubunda yer alırken 70’i (\%45.5) COVID(-) grubunda yer ald1. Tablo 1, grupların birinci bölüm yanıtları açısından karşılaştırılmasını içermektedir. İki grup arasında yaş, cinsiyet, sistemik hastalık (diyabet, hipertansiyon, kardiyovasküler hastalık, hiperkolesterolemi, astım, kronik obstruktif akciğer hastalığı) varlığı ve hastalığa bağlı ilaç kullanımı açısından istatistiksel olarak anlamlı farklılık bulunmazken sigara alışkanlığı açısından farklılık tespit edildi. Sigara içen kişi sayısı COVID(-) grubunda daha fazla bulundu $(\mathrm{p}=0.034)$.

Mann Whitney U testinin sonuçlarına göre iki grubun ortalama DH, ÇH ve PH ölçek değerleri kıyaslandığında DH ve $\mathrm{PH}$ ölçeği COVID(-) grubunda daha yüksek değerler gösterirken ÇH ölçeği COVID(+) grubunda daha yüksek olarak tespit edildi (Tablo 2). Ancak bu farklılıklar istatistiksel olarak anlamlı bulunmadı.

İki grubun ölçek aralıklarında (düşük, orta, yüksek) dağ1lımının kıyaslanması Tablo 3, 4 ve 5’te yer almaktadır. İki gruptaki hastaların her üç ölçekte dağılımı açısından istatistiksel olarak anlamlı farklılık görülmedi. Katılımcıların çoğunluğunun DH ve ÇH ölçeğinde düşük ve orta aralıkta yer aldığı belirlenirken yüksek değer aralığında en fazla katılımcının PH ölçeğinde bulunduğu belirlendi.

\section{TARTIŞMA}

Sağlık hizmetlerine ulaşımın kısıtlı olduğu alanlarda (ordu, kırsal alan vb.) dental hizmetlerin kolaylaştırılması amacıyla doksanlı yılların ortasında uygulanmaya başlanan teledişhekimliği; maliyeti ve zaman kaybını azaltma, riskli grupları belirleme gibi avantajlarının yanı sıra ağız sağlığını her koşulda idame etme konusunda da fayda sağlamaktadır. $^{20,21}$ Teledişhekimliği, COVID-19 pandemisi sırasında kalabalık popülasyonların diş hekimliği hizmeti verilen alanlarda birikiminin önlenmesi açısından ideal bir konsültasyon yöntemi olabilir.

Pandemi döneminde telefon konsültasyonu şeklinde teledişhekimliğinin uygulandığı ve sonuç olarak hastaların deneyimlerinin değerlendirildiği bir çalışmada katılımc1ların büyük çoğunluğu (\%94) bu uygulamadan memnun kaldıklarını belirtmişlerdir. ${ }^{22}$ Çocuk diş hekimliği alanında yapılmış bir çalışma ise pandemi döneminde telefon

\begin{tabular}{|c|c|c|c|c|c|c|c|c|}
\hline & \multicolumn{7}{|c|}{ Grup } & \multirow{3}{*}{$\mathrm{P}$} \\
\hline & & \multicolumn{3}{|c|}{$\operatorname{COVID}(+)$} & \multicolumn{3}{|c|}{$\operatorname{COVID}(-)$} & \\
\hline & & $\mathrm{n}$ & $\%$ (Satır) & $\%$ (Sütun) & $\mathrm{n}$ & $\%$ (Satır) & $\%$ (Sütun) & \\
\hline \multirow{2}{*}{ Cinsiyet } & Erkek & 27 & $51.9 \%$ & $32.1 \%$ & 25 & $48.1 \%$ & $35.7 \%$ & \multirow{2}{*}{0.383} \\
\hline & Kadın & 57 & $55.9 \%$ & $67.9 \%$ & 45 & $44.1 \%$ & $64.3 \%$ & \\
\hline \multirow{2}{*}{ Sistemik Hastalık } & $(+)$ & 26 & $60.5 \%$ & $31.0 \%$ & 17 & $39.5 \%$ & $24.3 \%$ & \multirow{2}{*}{0.231} \\
\hline & $(-)$ & 58 & $52.3 \%$ & $69.0 \%$ & 53 & $47.7 \%$ & $75.7 \%$ & \\
\hline \multirow{2}{*}{ İlaç Kullanımı } & $(+)$ & 25 & $65.8 \%$ & $29.8 \%$ & 13 & $34.2 \%$ & $18.6 \%$ & \multirow{2}{*}{0.078} \\
\hline & $(-)$ & 59 & $50.9 \%$ & $70.2 \%$ & 57 & $49.1 \%$ & $81.4 \%$ & \\
\hline \multirow{2}{*}{ Sigara Alışkanlığı } & $(+)$ & 22 & $43.1 \%$ & $26.2 \%$ & 29 & $56.9 \%$ & $41.4 \%$ & \multirow{2}{*}{0.034} \\
\hline & $(-)$ & 62 & $60.2 \%$ & $73.8 \%$ & 41 & $39.8 \%$ & $58.6 \%$ & \\
\hline
\end{tabular}

\begin{tabular}{|l|c|c|c|c|c|c|c|}
\hline & Ortalama & SS & Medyan & Ortalama & SS & Medyan & p \\
\hline Yaş & 40.44 & 14.96 & 37.50 & 41.37 & 10.28 & 41.00 & 0.649 \\
\hline
\end{tabular}

${ }^{\star}$ Chi-Square test, Mann Whitney U test 
J Biotechnol and Strategic Health Res. 2021;5(3):200-206

GÜRBÜZ, CEYLAN, COVID-19 ile Oral Hijyen Arasındaki İlişki

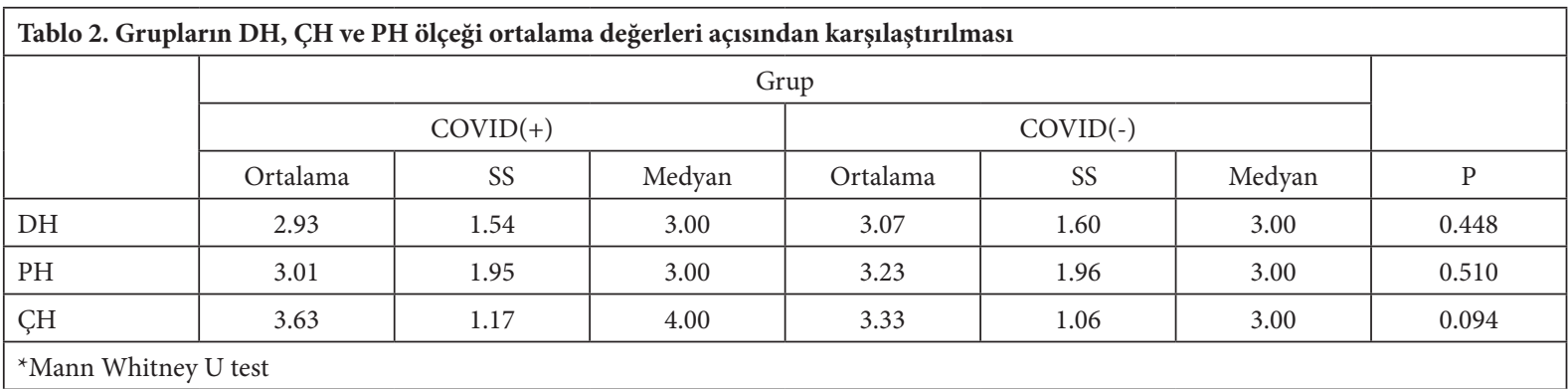

\begin{tabular}{|c|c|c|c|c|c|c|}
\hline & & & \multicolumn{2}{|c|}{ Grup } & \multirow[b]{2}{*}{ TOPLAM } & \multirow[b]{2}{*}{$\mathrm{p}$} \\
\hline & & & $\operatorname{COVID}(+)$ & $\operatorname{COVID}(-)$ & & \\
\hline \multirow{9}{*}{ DH } & \multirow{3}{*}{ Düşük } & Sayı & 39 & 27 & 66 & \multirow{12}{*}{0.565} \\
\hline & & \% DH içinde & $59.1 \%$ & $40.9 \%$ & $100.0 \%$ & \\
\hline & & $\%$ Grup içinde & $46.4 \%$ & $38.6 \%$ & $42.9 \%$ & \\
\hline & \multirow{3}{*}{ Orta } & Sayı & 35 & 35 & 70 & \\
\hline & & \% DH içinde & $50.0 \%$ & $50.0 \%$ & $100.0 \%$ & \\
\hline & & $\%$ Grup içinde & $41.7 \%$ & $50.0 \%$ & $45.5 \%$ & \\
\hline & \multirow{3}{*}{ Yüksek } & Sayı & 10 & 8 & 18 & \\
\hline & & \% DH içinde & $55.6 \%$ & $44.4 \%$ & $100.0 \%$ & \\
\hline & & $\%$ Grup içinde & $11.9 \%$ & $11.4 \%$ & $11.7 \%$ & \\
\hline \multirow{3}{*}{\multicolumn{2}{|c|}{ Toplam }} & Say1 & 84 & 70 & 154 & \\
\hline & & \% DH içinde & $54.5 \%$ & $45.5 \%$ & $100.0 \%$ & \\
\hline & & \% Grup içinde & $100.0 \%$ & $100.0 \%$ & $100.0 \%$ & \\
\hline
\end{tabular}

\begin{tabular}{|c|c|c|c|c|c|c|}
\hline & & & \multicolumn{2}{|c|}{ Grup } & \multirow[b]{2}{*}{ TOPLAM } & \multirow[b]{2}{*}{$\mathrm{p}$} \\
\hline & & & $\operatorname{COVID}(+)$ & COVID(-) & & \\
\hline \multirow{9}{*}{ PH } & \multirow{3}{*}{ Düşük } & Sayı & 38 & 26 & 64 & \multirow{12}{*}{0.339} \\
\hline & & \% PH içinde & $59.4 \%$ & $40.6 \%$ & $100.0 \%$ & \\
\hline & & \% Grup içinde & $45.2 \%$ & $37.1 \%$ & $41.6 \%$ & \\
\hline & \multirow{3}{*}{ Orta } & Say1 & 21 & 25 & 46 & \\
\hline & & \% PH içinde & $45.7 \%$ & $54.3 \%$ & $100.0 \%$ & \\
\hline & & $\%$ Grup içinde & $25.0 \%$ & $35.7 \%$ & $29.9 \%$ & \\
\hline & \multirow{3}{*}{ Yüksek } & Say1 & 25 & 19 & 44 & \\
\hline & & \% PH içinde & $56.8 \%$ & $43.2 \%$ & $100.0 \%$ & \\
\hline & & $\%$ Grup içinde & $29.8 \%$ & $27.1 \%$ & $28.6 \%$ & \\
\hline \multirow{3}{*}{\multicolumn{2}{|c|}{ Toplam }} & Say1 & 84 & 70 & 154 & \\
\hline & & \% PH içinde & $54.5 \%$ & $45.5 \%$ & $100.0 \%$ & \\
\hline & & \% Grup içinde & $100.0 \%$ & $100.0 \%$ & $100.0 \%$ & \\
\hline
\end{tabular}


J Biotechnol and Strategic Health Res. 2021;5(3):200-206

GÜRBÜZ, CEYLAN, COVID-19 ile Oral Hijyen Arasındaki İlişki

\begin{tabular}{|c|c|c|c|c|c|c|}
\hline & & & \multicolumn{2}{|c|}{ Grup } & \multirow[b]{2}{*}{ TOPLAM } & \multirow[b]{2}{*}{$\mathrm{p}$} \\
\hline & & & $\operatorname{COVID}(+)$ & $\operatorname{COVID}(-)$ & & \\
\hline \multirow{9}{*}{ ÇH } & \multirow{3}{*}{ Düşük } & Sayı & 16 & 18 & 34 & \multirow{12}{*}{0.417} \\
\hline & & \% ÇH içinde & $47.1 \%$ & $52.9 \%$ & $100.0 \%$ & \\
\hline & & $\%$ Grup içinde & $19.0 \%$ & $25.7 \%$ & $22.1 \%$ & \\
\hline & \multirow{3}{*}{ Orta } & Sayı & 67 & 52 & 119 & \\
\hline & & \% ÇH içinde & $56.3 \%$ & $43.7 \%$ & $100.0 \%$ & \\
\hline & & \% Grup içinde & $79.8 \%$ & $74.3 \%$ & $77.3 \%$ & \\
\hline & \multirow{3}{*}{ Yüksek } & Sayı & 1 & 0 & 1 & \\
\hline & & \% ÇH içinde & $100.0 \%$ & $0.0 \%$ & $100.0 \%$ & \\
\hline & & \% Grup içinde & $1.2 \%$ & $0.0 \%$ & $.6 \%$ & \\
\hline \multirow{3}{*}{\multicolumn{2}{|c|}{ Toplam }} & Sayı & 84 & 70 & 154 & \\
\hline & & \% ÇH içinde & $54.5 \%$ & $45.5 \%$ & $100.0 \%$ & \\
\hline & & \% Grup içinde & $100.0 \%$ & $100.0 \%$ & $100.0 \%$ & \\
\hline
\end{tabular}

yoluyla uygulanan ilk randevunun yüz yüze randevu sayısını üçte bir oranında azalttığını vurgulamıştır. ${ }^{23}$

Bu kesitsel çalışma ile periodontal hastalık nüksünü önlemede düzenli hasta kontrolünün önemi ${ }^{24}$ göz önünde bulundurularak, sosyal mesafe kısıtlaması ve karantina koşullarında telefon ile konsültasyonun oral hijyeni idame etmede ve riskli bireyleri belirlemede etkili olabileceği düşünülmüştür. Ancak bu husus başka bir çalışma konusu olduğu için bu çalışmanın kapsamında oral hijyen eğitimine veya hasta memnuniyetine değinilmemiştir.

Uygulanan anket çalışması ile katılımcıların COVID-19 hikayelerine göre oral hijyen alışkanlıkları ve periodontal hastalık hikayeleri değerlendirilmiştir. Alınan sonuçlara göre yaş, cinsiyet ve sistemik hastalık varlığı açısından iki grup arasında anlamlı farklılık bulunmazken sigara alışkanlığı yönünden farklılık tespit edilmiştir. Literatürdeki sigaranın ACE-2 reseptörünün ekspresyonunu artırdığı bilgisi, sigara içen bireylerde COVID-19 riskinin artabileceği sonucunu ortaya çıkarmıştır. ${ }^{25}$ Ancak yapılan bir meta-analizde aktif sigara içiciliğinin COVID-19 seyriyle ilişkilendirilemeyeceği vurgulanmıştır. ${ }^{26}$ Yine de yazarlar sağlığı birçok yönden olumsuz şekilde etkileyen sigaranın
COVID-19 ile olan karmaşık ilişkisini netleştirecek ileri çalışmalara ihtiyaç olduğu yorumunu yapmışlardır. ${ }^{27}$

Oral hijyen alışkanlığının ve periodontal hastalık hikayesinin değerlendirilmesi amacıyla oluşturulan $\mathrm{DH}$, ÇH ve PH ölçeklerinin ortalama değerleri ve katılımcıların ölçek aralıklarında dağılımı gruplar arasında istatistiksel farklılık göstermemiştir. Literatürde COVID-19 ve periodontal hastalık ilişkisini inceleyen az sayıda çalışma bulunmaktadır. ${ }^{28-31}$ Bir vaka-kontrol çalışmasında yalnızca COVID-19 hastaları değerlendirilmiş olup periodontal hastalık ile COVID-19'un ciddi komplikasyonları (hastaneye yatış, yoğun bakım ünitesinde tedavi görme, mekanik ventilasyon, ölüm vb.) arasında ilişki olup olmadığı incelenmiş ve periodontal hastalığın COVID-19 komplikasyon riskini artırdığı sonucuna varılmıştır. ${ }^{28} \mathrm{Bu}$ anket çalışmasında ise katılımcıların hastaneye yatış gibi COVID-19 seyrini temsil eden komplikasyonlarının değerlendirilmemesi, istatistiksel sonuçlarda farklılık görülmemesinde etken olabilir ve bu sonuçlar, bireylerin COVID-19'u düşük şiddette atlatmış olmasından kaynaklanabilir. Ancak benzer hasta kabul dizaynının uygulandığı ve hastalık seyrinin dikkate alınmadığı bir çalışmada klinik olarak periodontal indekslerle COVID-19 pozitif ve COVID-19 negatif hastalar k1- 
yaslanmış, sonuçlarda periodontitis şiddeti ile COVID-19 ilişkilendirilmiş ve periodontal sağlık ile ağız hijyeninin idame ettirilmesinin COVID-19'u kontrol altına alma açısından önemli olduğu vurgulanmıştır. ${ }^{31}$

Çalışmamıza benzer şekilde hasta beyanına dayalı periodontal durumun değerlendirildiği bir çalışmada periodontal hastalığın COVID-19 riskini artırdığına dair yeterli kanıt bulunamamıştır. ${ }^{29}$ Bahsi geçen çalışmanın yazarlarının yayınladıkları bir sonraki çalışmada obezitenin ve periodontal hastalığın COVID-19 üzerine etkisi incelenmiş ve obezitenin periodontal durumdan daha belirgin bir şekilde COVID-19'u etkilediği, ancak periodontal hastalığın obezitenin etkisini şiddetlendirebileceği sonucuna varılmıştır. ${ }^{30}$ Bu sonuç periodontal hastalığın sistemik hastalık varlığında COVID-19'u etkileyebileceğini düşündürmektedir. Çalışmamıza bakıldığında ise sistemik hastalığı olan bireyler dahil edilmiş, ancak gruplar arasında hastalık varlığı açısından fark tespit edilmemiştir.

COVID-19 pandemisinin getirdiği sınırlamalar nedeniyle, çalışmamızla aynı tasarımda yapılan bir çalışmada, anket ile ağız hijyeni durumunun COVID-19 seyrine etkisi incelenmiş ve sonuç olarak şiddetli COVID-19 vakalarında zayıf hijyen durumu gösterilerek oral hijyenin COVID-19 seyrini etkileyebileceği vurgulanmıştır. ${ }^{19}$ Çalışmamızdan farklı olarak bahsi geçen çalışmaya sigara içen bireyler ve diyabet, hipertansiyon gibi hastalığı olan bireyler dahil edilmemiştir.

$\mathrm{Bu}$ kesitsel çalışmanın birtakım sınırlamaları vardır. COVID-19 hikayesinin Polimeraz zincir reaksiyonu testi sonucundan ziyade hasta beyanına dayalı olması gerçek veriyi elde etmeyi zorlaştırabilir. Aynı şekilde anket uygulamasında hastaların özellikle hijyen sorularında olumlu yanıt verme yönünde bir baskı hissetmeleri de muhtemeldir. Ölçek sonuçları da göstermiştir ki hastalar çoğunlukla düşük ve orta aralıklarda yer almışlardır.

Çalışmamızda hijyen ve periodontal durum açısından iki grup arasında farklılık görülmemiştir. Bu sonuç, $\mathrm{CO}-$ VID-19 komplikasyon veri eksikliğine ve sonucu etkileyebilecek birtakım faktörlerin dışlanmamasına bağlı olabilir. Aynı zamanda pandeminin getirdiği kısıtlamalar nedeniyle klinik indekslerle çalışma yönteminin gerçekleştirilmemesi de bir diğer sınırlamadır.

\section{SONUÇLAR}

COVID-19 pandemisinin başlangıcından bu yana oldukça zaman geçmiş olmasına ve bu hastalık üzerine oldukça fazla çalışma yapılmış olmasına rağmen halen bireyleri enfeksiyona yatkın kılan sebepler gizemini korumaktadır. Oral hijyenin ve periodontal hastalığın COVID-19 ile ilişkisi üzerine yapılmış bu çalışmada ilişkiyi destekleyecek kanıt elde edilememiştir ve teledişhekimliğiyle belirlenen periodontal açıdan riskli bireylerin yer aldığı, COVID-19 komplikasyon verilerine yer verilen, katılımcı sayısının fazla olduğu ileri klinik çalışmalara ihtiyaç vardır.

\section{Açıklamalar:}

Çalışmayı maddi olarak destekleyen kişi/kuruluş yoktur ve yazarların herhangi bir çıkar dayalı ilişkisi yoktur.

Çalışma protokolü, T.C. Sağlık Bakanlığı Bilimsel Araştırma Platformu (No. 2021-03 20T16_25_47) ve Kütahya Sağlık Bilimleri Üniversitesi Girişimsel Olmayan Klinik Araştırmalar Etik Kurulu (Karar No: 2021/06-21) tarafından onaylandı. Çalışma, Helsinki Deklerasyonu Prensipleri dikkate alınarak uygulandı. 
J Biotechnol and Strategic Health Res. 2021;5(3):200-206

GÜRBÜZ, CEYLAN, COVID-19 ile Oral Hijyen Arasındaki İlişki

\section{Kaynaklar}

1. Belser JA, Rota PA, Tumpey TM. Ocular tropism of respiratory viruses. Microbiol Mol Biol Rev. 2013;77(1):144-56.

2. To KK-W, Tsang OT-Y, Yip CC-Y, Chan K-H, Wu T-C, Chan JM-C, et al. Consistent detection of 2019 novel coronavirus in saliva. Clin Infect Dis. 2020;71(15):841-3.

3. Chen N, Zhou M, Dong X, Qu J, Gong F, Han Y, et al. Epidemiological and clinical characteristics of 99 cases of 2019 novel coronavirus pneumonia in Wuhan, China: a descriptive study. Lancet. 2020;395(10223):507-13.

4. Liu L, Wei Q, Alvarez X, Wang H, Du Y, Zhu H, et al. Epithelial cells lining salivary gland ducts are early target cells of severe acute respiratory syndrome coronavirus infection in the upper respiratory tracts of rhesus macaques. J Virol. 2011;85(8):4025-30.

5. Peng X, Xu X, Li Y, Cheng L, Zhou X, Ren B. Transmission routes of 2019-nCoV and controls in dental practice. Int J Oral Sci. 2020;12(1):1-6

6. Wang W-K, Chen S-Y, Liu I-J, Chen Y-C, Chen H-L, Yang C-F, et al. Detection of SARS-associated coronavirus in throat wash and saliva in early diagnosis. Emerg Infect Dis. 2004;10(7):1213.

7. Robba C, Battaglini D, Pelosi P, Rocco PR. Multiple organ dysfunction in SARS-CoV-2: MODS-CoV-2. Expert Rev Respir Med. 2020;14(9):865-8.

8. Chen N, Zhou M, Dong X, Qu J, Gong F, Han Y, et al. Epidemiological and clinical characteristics of 99 cases of 2019 novel coronavirus pneumonia in Wuhan, China: a descriptive study. Lancet. 2020;395(10223):507-13.

9. Pitones-Rubio V, Chávez-Cortez EG, Hurtado-Camarena A, González-Rascón A, Serafín-Higuera N. Is periodontal disease a risk factor for severe COVID-19 illness? Med Hypotheses. 2020;144:109969.

10. Sahni V, Gupta S. COVID-19 \& Periodontitis: The cytokine connection. Med Hypotheses. 2020;144:109908.

11. Scannapieco FA. Role of oral bacteria in respiratory infection. J Periodontol 1999;70(7):793-802

12. Takahashi Y, Watanabe N, Kamio N, et al. Aspiration of periodontopathic bacteria due to poor oral hygiene potentially contributes to the aggravation of COVID-19. J Oral Sci 2020;63(1):1-3

13. Garcia-Huidobro D, Rivera S, Valderrama Chang S, Bravo P, Capurro D. System-wide accelerated implementation of telemedicine in response to COVID-19: Mixed methods evaluation. J Med Internet Res. 2020;22(10):e22146.

14. Khan SA, Omar H. Teledentistry in practice: literature review. Telemed J E Health. 2013;19(7):565-7.

15. Rocca MA, Kudryk VL, Pajak JC, Morris T. The evolution of a teledentistry system within the Department of Defense. Proc AMIA Symp. 1999:921-4.

16. González-Olmo MJ, Delgado-Ramos B, Ruiz-Guillén A, Romero-Maroto M, Carrillo-Díaz M. Oral hygiene habits and possible transmission of COVID-19 among cohabitants. BMC Oral Health 2020;20(1):286.

17. Gilbert AD, Nuttall NM. Self-reporting of periodontal health status. Br Dent J 1999;186(5):241-4.

18. Ruíz-López Del Prado G, Blaya-Nováková V, Saz-Parkinson Z, et al. [Design and validation of an oral health questionnaire for preoperative anaesthetic evaluation]. Rev Bras Anestesiol 2017;67(1):6-14.

19. Kamel AHM, Basuoni A, Salem ZA, AbuBakr N. The impact of oral health status on COVID-19 severity, recovery period and C-reactive protein values. Br Dent J 2021:1-7.

20. Daniel SJ, Kumar S. Teledentistry: a key component in access to care. J Evid Based Dent Pract. 2014;14 Suppl:201-8.

21. Rockwell KL, Gilroy AS. Incorporating telemedicine as part of COVID-19 outbreak response systems. Am J Manag Care. 2020;26(4):147-8.

22. Rahman N, Nathwani S, Kandiah T. Teledentistry from a patient perspective during the coronavirus pandemic. Br Dent J. 2020:1-4.

23. Wallace CK, Schofield CE, Burbridge LAL, O'Donnell KL. Role of teledentistry in paediatric dentistry. Br Dent J. 2021:1-6.

24. Axelsson P, Lindhe J. The significance of maintenance care in the treatment of periodontal disease. J Clin Periodontol. 1981;8(4):281-94.

25. Leung JM, Yang CX, Tam A, Shaipanich T, Hackett TL, Singhera GK, et al. ACE-2 expression in the small airway epithelia of smokers and COPD patients: implications for COVID-19. Eur Respir J. 2020;55(5).

26. Lippi G, Henry BM. Active smoking is not associated with severity of coronavirus disease 2019 (COVID-19). Eur J Intern Med. 2020;75:107-8.

27. Lippi G, Sanchis-Gomar F, Henry BM. Active smoking and COVID-19: a double-edged sword. Eur J Intern Med. 2020;77:123-4.

28. Marouf N, Cai W, Said KN, Daas H, Diab H, Chinta VR, et al. Association between periodontitis and severity of COVID-19 infection: A case-control study. J Clin Periodontol. 2021;48(4):483-91.

29. Larvin H, Wilmott S, Wu J, Kang J. The impact of periodontal disease on hospital admis sion and mortality during COVID-19 pandemic. Front Med (Lausanne). 2020;7:604980

30. Larvin H, Wilmott S, Kang J, Aggarwal VR, Pavitt S, Wu J. Additive effect of periodontal disease and obesity on COVID-19 outcomes. J Dent Res. 2021:220345211029638.

31. Anand PS, Jadhav P, Kamath KP, Kumar SR, Vijayalaxmi S, Anil S. A case-control study on the association between periodontitis and coronavirus disease (COVID-19). J Periodontol. 10.1002/JPER.21-0272. Published online: 4 August 2021. 